\title{
ВЛИЯНИЕ СОСТАВА ПАСТБИЩА И КЛИМАТИЧЕСКИХ УСЛОВИЙ НА ПРОДУКТИВНОСТЬ ТЕЛЯТ ПОРОДЫ АБЕРДИН-АНГУС
}

\author{
Т. В. ИВАНОВА ${ }^{1}, \quad$ П. И. ЛЮЦКАНОВ ${ }^{2}, \quad$ Р. Й. КАЛЕВ ${ }^{3}, \quad$ Т. И. БОЖАНСКА ${ }^{4}$, \\ М. Н. ИЛИЕВ ${ }^{4}$, В. М. ГАЙДАРСКА \\ ${ }^{1}$ Сельскохозяйственный институт (Шумен, Республика Болгария) \\ ${ }^{2}$ Научно-практический институт биотехнологии в зоотехнии и ветеринарной Медицины \\ (Максимовка, Республика Молдова) \\ ЗЭкспериментальная станиия сельского хозяйства (Тарговиште, Республика Болгария) \\ ${ }^{4}$ Институт горного животноводства и сельского хозяйства (Троян, Республика Болгария) \\ ${ }^{5}$ Институт животноводных наук (Костинброд, Республика Болгария)
}

Исследования проводились в 2017 году в районе Песакки в селе Йосифова Монтана в стаде ООО «ТРЕЙС АНГАС ФАРМ» с мая по октябрь (пастбищный период). Была сформирована группа из 10 телят мясной породы абердин-ангус, аналоги по полу (бычки), возрасту (отбитые в апреле) и живому весу. Животные содержались на протяжении всего экспериментального периода на лугопастбищных угодьях, питались только травой, а во втором экспериментальном периоде их кормили 1,5 кг кукурузной дерти. Результаты исследований показывают, что у сформировавшегося в мае месяие травостоя было высокое содержание сырой клетчатки, сырых жиров, минеральных веществ, кальция и фосфора, но более низкое со-

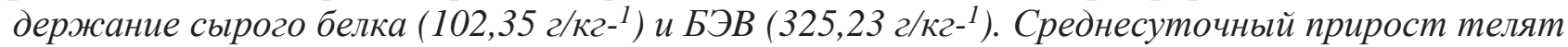
в группе породы абердин-ангус был несколько ниже в мае, июне и июле и колебался от 0,487 кг до 0,597 кг. Дополнительный корм с кукурузной дертью позволил значительно его увеличить (1200 2-1680 2), увеличение наблюдалось в августе, сентябре и октябре. Данные по ботаническому составу трав показывают, что в травостое в основном яровые и разнотравные виды, а прочент бобовых культур слабо выражен. Метеорологические условия, температура и количество осадков влияли на состояние травостоя опытного пастбища.

Ключевые слова: пастбища, травостой, злаковые, бобовые, разнотравные, телята, среднесуточный прирост, температура, осадки

\section{INFLUENCE OF GRASSLAND COMPOSITION AND CLIMATE CONDITIONS ON THE PRODUCTIVITY OF ABERDEEN-ANGUS CALVES}

T. V. Ivanova ${ }^{1}$, P. I. Lutskanov ${ }^{2}$, R. Y. Kalev ${ }^{3}$, T. I. Bozhanska ${ }^{4}$, M. N. Iliev ${ }^{4}$, V. M. Gajdarska ${ }^{1}$ Agricultural Institute (Shumen, Republic of Bulgaria)

${ }^{2}$ Scientific and Practical Institute of Biotechnologies in Zootechnics and Veterinary Medicine (Maksimovka, Republic of Moldova)

${ }^{3}$ Agricultural Experimental Station (Targovishte, Republic of Bulgaria)

${ }^{4}$ Research Institute of Mountain Stockbreeding and Agriculture (Troyan, Republic of Bulgaria)

${ }^{5}$ Institute of Animal Science (Kostinbrod, Republic of Bulgaria)

The research has been conducted in 2017 in the "Pesaka" area of "Dr. Yosifov" village, Montana province in the herd of "TRACE ANGUS FARM" Ltd. from May to October (grazing period). A group of 10 Aberdeen Angus calves equaled by gender (male), age (weaned in April) and live weight. The animals remained outdoors during the entire experimental period (grazing), were fed only with grass, and in the second experimental period were fed only with $1.5 \mathrm{~kg}$ of corn mash. The research results show that the grassland formed during May has a higher content of Crude fibers, Crude fats, Mineral substances, Calcium and Phosphorus, but a low level of Crude Protein $\left(102,35 \mathrm{~g} / \mathrm{kg}^{-1}\right)$ and Non-saturated Extract Substances $\left(325,23 \mathrm{~g} / \mathrm{kg}^{-1}\right)$. The average daily growth of calves in the group is lower during the months of May, June and July and varies from $0.487 \mathrm{~kg}$ to $0.597 \mathrm{~kg}$. Additional 
feeding with corn mash allowed for a significant higher growth $(1200 \mathrm{~g}-1680 \mathrm{~g})$ in the observed group during August, September and October. Data from the botanical composition of grassland shows that living species and motley grasses are the main identifiers in grassland, and the share of legumes is poorly expressed. Meteorological conditions, temperature and rainfall have an impact on the conditions of grass in the pasture.

Keywords: pasture, grassland, grasses, legumes, motley grasses, calves, average daily growth, temperature, rainfall

\section{ВПЛИВ СКЛАДУ ПАСОВИЩ І КЛІМАТИЧНИХ УМОВ НА ПРОДУКТИВНІСТЬ ТЕЛЯТ ПОРОДИ АБЕРДИН-АНГУС}

Т. В. Іванова 1 , П. І. Люцканов ${ }^{2}$, Р. Й. Калев ${ }^{3}$, Т. І. Божанска ${ }^{4}$, М. Н. Іліев ${ }^{4}$, В. М. Гайдарска $^{5}$

${ }^{1}$ Сельскохозяйственний інститут (Шумен, Республіка Болгарія)

${ }^{2}$ Научно-практичний інститут біотехнології в зоотехнії і ветеринарної Медицини (Максимівка, Республіка Молдова)

${ }^{3}$ Експериментальна станція сільського господарства (Тарговіште, Республіка Болгарія)

${ }^{4}$ Інститут гірського тваринництва і сільського господарства (Троян, Республіка Болгарія)

${ }^{5}$ Інститут животноводних наук (Костинброд, Республіка Болгарія)

Дослідження проводилися в 2017 роиі в районі Песаккі в селі Йосифові Монтана в стаді ТОВ «ТРЕЙС АНГАС ФАРМ» з травня по жовтень (пасовищний період). Була сформована група з 10 телят м'ясної породи абердин-ангус, аналоги за статтю (бички), віком (відбиті в квітні) та живою вагою. Тварини утримувалися протягом усього експериментального періоду на лукопасовищних угіддях, харчувалися тільки травою, а в другому експериментальному періоді їх годували 1,5 кг кукурудзяної дерті. Результати досліджень показують, щуо у сформованого в травні місяиі травостою високий вміст сирої клітковини, сирих жирів, мінеральних речовин, кальциію і фосфору, але більш низький вміст сирого білка $\left(102,35\right.$ г/кг-- $\left.{ }^{1}\right)$ БЭВ (325,23 г/кг-1). Середньодобовий приріст телят в групі породи абердин-ангус трохи нижче в травні, червні та липні і коливався від 0,487 кг до 0,597 кг. Додатковий корм з кукурудзяної дерті дозволив значно його збільшити (1200 2-1680 г), збільшення спостерігалося в серпні, вересні та жовтні. Дані по ботанічному складу трав показують, щуо в травостої в основному ярі і різнотравні види, а відсоток бобових культур слабо виражений. Метеорологічні умови, температура $і$ кількість опадів впливали на стан травостою дослідного пасовища.

Ключові слова: пасовища, травостій, злакові, бобові, різнотравні, телята, середньодобовий приріст, температура, опади

Введение. Основной функцией пастбищ является производство кормов для жвачных животных, которые являются источником биомассы для получения энергии, защиты почвы от водной и ветровой эрозии, обогащают небольшую часть $\mathrm{CO}_{2}$.

Пастбищная система откорма - многообещающая и пригодная для экологического производства. Обеспечение достаточной массы травы, своевременное начало и окончание выпаса на отдельных участках, регулярный контроль высоты и урожайности обеспечивают максимальное потребление зеленой массы [1].

Удовлетворение питательными веществами с пастбищ зависит от его питательного состава, усвояемости, а также от его ежедневного использования [2]. В сухих средиземноморских регионах сезон пастбищ невелик, а изменения в питательном качестве травы высокие (снижение белка на 17\% в сухом веществе в начале апреля, до 7,1\% в июне и $6,3 \%$ в октябре) и наступают быстро [3].

В своих исследованиях Тодорова П. [4] и Todorova P. and Kirilov A. [5] сообщили о значительном изменении состава, пищевой энергии и минерального состава пастбищной травы из центрального Балканского региона. Согласно Todorova et al. [6] урожайность зеленой массы и сухие вещества пастбищ уменьшаются по мере увеличения высоты. Длительность выпаса 
животных очень важна для массового восстановления травы. В странах с хорошими пастбищами на пастбище практикуется постоянное или временное ограждение и размещение животных. Это обеспечивает непрерывный выпас, который обычно является самым интенсивным утром и поздним вечером в летний период [7, 8].

При использовании пастухов и загоняя телят на ферму или под навесами животные в самые благоприятные часы лишены возможности пастись, а время выпаса уменьшается на $36 \%$. Тодоров М. [8] считал важным условием достижения хороших результатов, обеспечивающих 24-часовое пастбище без пастуха. Животные предпочитали пастись утром и вечером. В Болгарии 271 день сравнительно длительный выпас был достигнут в мясных хозяйствах [9]. Российские ученые считают, что при наличии достаточно хорошего травостоя наиболее экономично откармливать крупный рогатый скот главным образом травой $[10,11]$.

Во всем мире наблюдается увеличение мясного скота, и это связано с погоней за более дешевым способом откорма. Таким образом, возникает так называемый комбинированный откорм - пастбище с разной продолжительностью аномального периода [12]. Одной из пород, которая приобрела особую популярность, является абердин-ангус. Мясо этой породы имеет превосходное качество - цвет, структуру, очень хорошая мраморность мяса, а животные хорошо адаптируются к условиям пастбищного откорма.

Целью этого исследования является определение влияния состава пастбищ и климатических условий на продуктивность телят мясного скота - абердин-ангус на территории региона Монтана (Стара Планина).

Материал и методы исследований. Исследования проводились в 2017 году в районе Песакки в селе Йосифова Монтана в стаде ООО «ТРЕЙС АНГАС ФАРМ» с мая по октябрь (пастбищный период). Была сформирована группа из 10 телят мясной породы абердин-ангус, аналоги по полу (бычки), возрасту (отбитые в апреле) и живому весу. Животные содержались на протяжении всего экспериментального периода на лугопастбищных угодьях, питались только травой, а во втором экспериментальном периоде их кормили 1,5 кг кукурузной дерти. У них был неограниченный доступ к воде. Проводилось взвешивание телят в течение пастбищного периода. Регистрировались средний живой вес и среднесуточный прирост по месяцам. Фиксировались факторы температуры воздуха $\left(\mathrm{T}^{0} \mathrm{C}\right)$ и осадки $\left(\mathrm{Mм} / \mathrm{M}^{2}\right)$ с учетом их влияния на рост животных.

Выход сухой массы (кг/га) определяется путем скашивания площади в каждой точке, сушки образцов растений в лабораторных условиях при $105^{\circ} \mathrm{C}$ и пересчета в зависимости от содержания сухого вещества. Ботанические изменения в пастбищах (\%) определяются весовым анализом проб травы, взятых непосредственно перед скашиванием, и определены процентные соотношения основных ботанических групп: злаковые, бобовые и разнотравья. Проанализирован основной химический состав сухой биомассы (средней пробы шести вариантов), который включает: сырой протеин (СП г кг-1), определенный методом Кьельдаля; сырой жир (СЖ, г кг-1) - экстракцией в экстракторе Сокслета; сырая клетчатка (СК, г кг-1) согласно анализу Weende; зола (г кг-1) в муфельной печи при $550^{\circ} \mathrm{C}$; кальций $(\mathrm{Ca}, \mathrm{g}$ кг-1) - в Щотц (комплексно-метрический); фосфор (Р, г кг-1) - это ванадат-молибдат реагента по методу Герике и Курмис, на спектрофотометре (Agilent 8453 UV - visible Spectroscopy System), измеренная при 425 ๆт и БЭВ (г кг-1) = 100 - (СП, \% + СВ, \% + СЖ, \% + зола, \% + влажность, \%). Волокнистые компоненты клеточных стенок были рассчитаны в процентах от сухого вещества и включают в себя: нейтральное детергентное волокно (НДВ, г-1 кг) кислоты детергентного волокна (КДВ, г кг-1) и кислота детергентная лигнина (КДЛ, г кг-1) по детергентному анализу. Полиизозиды, гемицеллюлоза и целлюлоза рассчитывались эмпирически. Степень лигнификации выражается в процентах от КДЛ /НДВ. Потенциальная энергетическая ценность корма была оценена в болгарской системе как KЕМ (кормовые единицы молока) и КЕР (кормовые единицы роста). Ферментативная перевариваемость ферментов in vitro сухого вещества (СМСB, g кг-1) методом двухфазного пепсин-целлюлозного метода. 
Результаты исследований. Пищевая ценность естественного травостоя. Пищевая ценность биомассы травы на пастбище зависит от стадии развития видов растений и является изменчивой величиной в разные месяцы года. Факторы, влияющие на этот показатель, связаны с соотношением структурных элементов (листьев : стеблей) в скошенной фуражной массе; содержание клеток; переваримость сухого и органического вещества и т. д. [13]. Химический состав травы, используемой породой абердин-ангус в течение испытательного периода в регионе Стара Планина, представлен в таблице 1.

1. Основной химический состав сухой фуражной массы $\left(2 / \kappa^{-1}\right)$

\begin{tabular}{|l|c|c|c|c|c|c|c|}
\hline Период (мес.) & ППказатель & СК & СЖ & $\begin{array}{c}\text { Минеральные } \\
\text { вещества }\end{array}$ & БЕВ & Са & Р \\
\hline Май & 102,35 & 468,88 & 23,35 & 80,19 & 325,23 & 13,99 & 2,16 \\
\hline Октябрь & 123,58 & 437,14 & 15,73 & 71,69 & 351,87 & 10,85 & 0,969 \\
\hline
\end{tabular}

Примечание: СП - сырой протеин; СК - сырая клетчатка; СМ - сырой жир; БЭВ - безазотистые экстрактивнье вещества; Са - кальцчий; $P$ - фосфор.

Скошенная в мае месяце фуражная масса, имеет высокие показатели по содержанию сырой клетчатки, сырого жира, минеральных веществ, кальция и фосфора и более низкие по сырому белку $\left(102,35\right.$ г кг- $\left.^{1}\right)$ и БЭВ $\left(325,23\right.$ г кг- $\left.{ }^{1}\right)$. Каждое пастбище представляет собой уникальное сочетание различных видов растений и сезонных изменений их состава, влияет на качественную оценку и питательную ценность природных пастбищ $[14,15]$. В пастбищном травостое в майском периоде выше содержание безводного лигнинового полимера - фактор, который влияет на степень переваримости растительной биомассы (табл. 2). Переваримость сухого вещества весеннего травостоя на 33,64\% ниже, чем у осеннего (734,92 г кг-1ํ).

2. Волоконные структурные компоненты клеточных стенок сухого корма (2/ $\left.2^{-1}\right)$

\begin{tabular}{|l|c|c|c|c|c|c|c|}
\hline Период (мес.) & НДВ & КДВ & КдЛ & $\begin{array}{c}\text { Гемицел- } \\
\text { люлоза }\end{array}$ & Клетчатка & $\begin{array}{c}\text { Степень лигни- } \\
\text { фикации }\end{array}$ & СМСВ \\
\hline Май & 720,19 & 430,79 & 278,06 & 289,40 & 152,73 & 38,61 & 549,92 \\
\hline Октябрь & 752,10 & 437,15 & 116,97 & 314,98 & 320,20 & 153,73 & 734,92 \\
\hline
\end{tabular}

Примечание: НДВ - нейтральное детергентное волокно; КДВ - кислоты детергентного волокна; КДЛкислоты детергентного лигнина; СМСВ - переваримость сухого вещества.

Количество нейтральных и кислотных детергенных веществ, а также гемицеллюлозы более высокие в октябре месяце. В сухой массе корма в осеннем периоде содержится 109,7\% клетчатки, что выше чем весной.

Показатели, определяющие энергетическую ценность естественных пастбищ, являются важным фактором качества полученного корма и его эффективного использования (табл. 3 ).

3. Энергетическая ценность сухой массы корма на кг корма

\begin{tabular}{|c|c|c|c|c|}
\hline $\begin{array}{ll}\text { Период (мес.) } & \text { Показатель } \\
\end{array}$ & $\mathrm{BE}$ & $\mathrm{OE}$ & KEM & КЕР \\
\hline Май & 18,66 & 7,57 & 0,69 & 0,61 \\
\hline Октябрь & 18,68 & 7,73 & 0,70 & 0,63 \\
\hline
\end{tabular}

Примечание: ВЕ - валовая энергия; ОЕ - обменная энергия; КЕМ - кормовые единицы молока; КЕР - кормовые единицы роста.

Валовые и обменные значения энергии близки и соответствуют средним значениям сухой массы горных лугов в «Стандартах для кормления скота и буйволов» - Тодоров (1995). Согласно полученным результатам, качество травы в течение пастбищного периода существенно не изменяется. Наблюдаемые изменения связаны с количественными параметрами состава травяных сообществ. 
Урожайность зеленой и сухой массы естественного травостоя и продуктивность телят породы абердин-ангус. Из данных таблицы 4 мы видим, что более высокой урожайностью зеленой и сухой массы отличался травостой, исследованный в мае $(1780,00$ кг/га и 684,23 кг/га соответственно).

4. Урожайность зеленой и сухой массы (кг/га)

\begin{tabular}{|c|c|c|}
\hline Период (мес.) & Зеленая масса & Сухая масса \\
\hline Май & 1780,00 & 684,23 \\
\hline Октябрь & 1360,00 & 435,2 \\
\hline
\end{tabular}

Согласно исследованиям Кириллова и др. [13] урожайность от наших естественных пастбищ низкая и варьируется от 2500 до 3000 кг/га сена. Полученный среднесуточный прирост (табл. 5) показывает, что в начале пастбищного периода телята имели привес (в среднем за месяцы май, июнь и июль - 0,584 кг), который получен только от выпаса. В течение второго периода, когда состав травы сохраняет питательную ценность, но урожайность снизилась в результате изменения климата, мы добавили подкормку - кукурузную дерть, в результате увеличился среднесуточный привес (в среднем за август, сентябрь и октябрь - 1,380 кг).

5. Средний живой вес и среднесуточный привес телят в течении периода исследований (кг)

\begin{tabular}{|c|c|c|c|}
\hline \multirow{2}{*}{ Месяц } & \multirow{2}{*}{$\mathrm{n}$} & \multicolumn{2}{|c|}{$\mathrm{X}+\mathrm{Sx}$} \\
\cline { 3 - 4 } & & \multicolumn{3}{|c|}{ Средняя живая масса } & $0.597+0,039$ \\
\hline Май & 10 & $313+9,609$ & $0.667+0,062$ \\
\hline Июнь & 10 & $333+9,570$ & $0.487+0,1285$ \\
\hline Июль & 10 & $348+11,555$ & $1.260+0,1272$ \\
\hline Август & 10 & $385+13,508$ & $1.200+0,1161$ \\
\hline Сентябрь & 10 & $421+12,574$ & $1.680+0,0641$ \\
\hline Октябрь & 10 & $472+13,579$ & $\mathbf{0 . 9 8 2}+\mathbf{0 , 0 6 7 4}$ \\
\hline В среднем & $\mathbf{1 0}$ & $\mathbf{3 7 9 + 8 , 4 8 6}$ & \\
\hline
\end{tabular}

Ботанический состав естественного травостоя в области Монтана (Стара Планина). Пастбища состоят из растений, принадлежащих к большому числу ботанических семейств, объединенных в следующие группы: злаковые, бобовые и травы других семейств (разнотравье). В естественных травостоях нашей страны преобладают злаковые травы. Доля бобовых в исследованиях Kirilova and Todorova [16] колеблется от 2 до 8\%. Низкая доля бобовых культур (растения с высоким содержанием белка) подразумевает и более низкую белковую ценность в сформированной биомассе.

На хороших лугах и пастбищах злаковые занимают 50-80\% травы, что связано с их более длительным сроком хранения и устойчивостью к неблагоприятным климатическим и почвенным условиям, а также их лучшей конкурентоспособностью по сравнению с видами других ботанических семейств. Бобовые имеют самую высокую пищевую ценность, но из-за их высоких требований к окружающей среде и более коротким срокам сохранности наличие в естественных лугах составляет 5-10\% (редко 20-30\%).

В группу разнотравий входят растения различной пищевой ценности, которые зависят от стадии развития во время использования. Их относительная доля колеблется от 5-10 до 5060\%. Наибольшим разнообразием являются виды этой группы на горных лугах и высокогорных пастбищах, на очень влажных лугах, а также на сухих холмистых пастбищах [17].

Согласно данным о ботаническом составе естественных пастбищ в регионе Монтана, используемых мясной породой абердин-ангус (рис. 1 и 2), злаковые травы преобладают и в основном с мая по октябрь месяц доминирующими видами являются: Festuca rubra ssp.comutata u Festuca pratenis.Huds. 


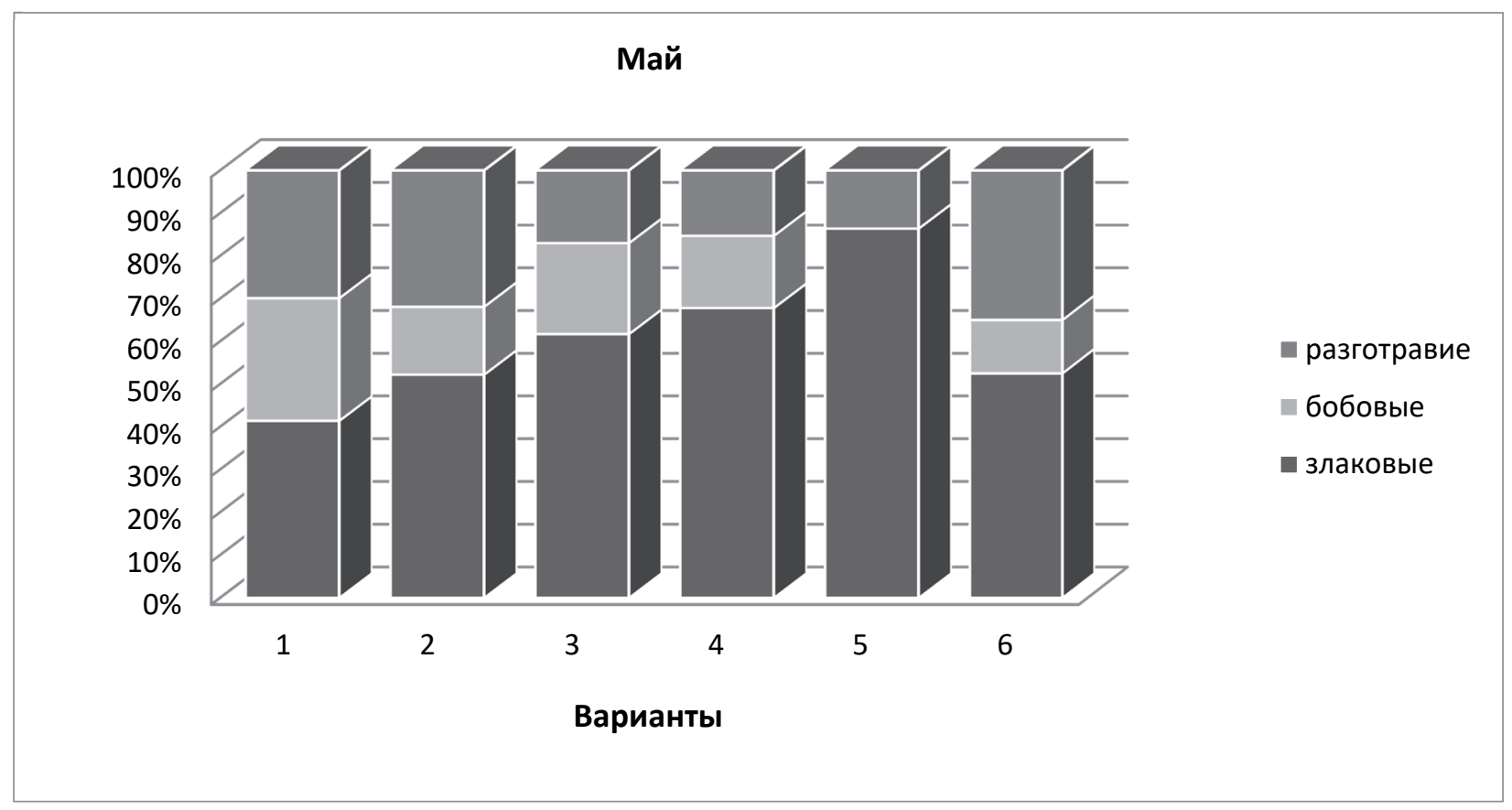

Рис. 1 Ботанический состав естественного травостоя в мае месяце

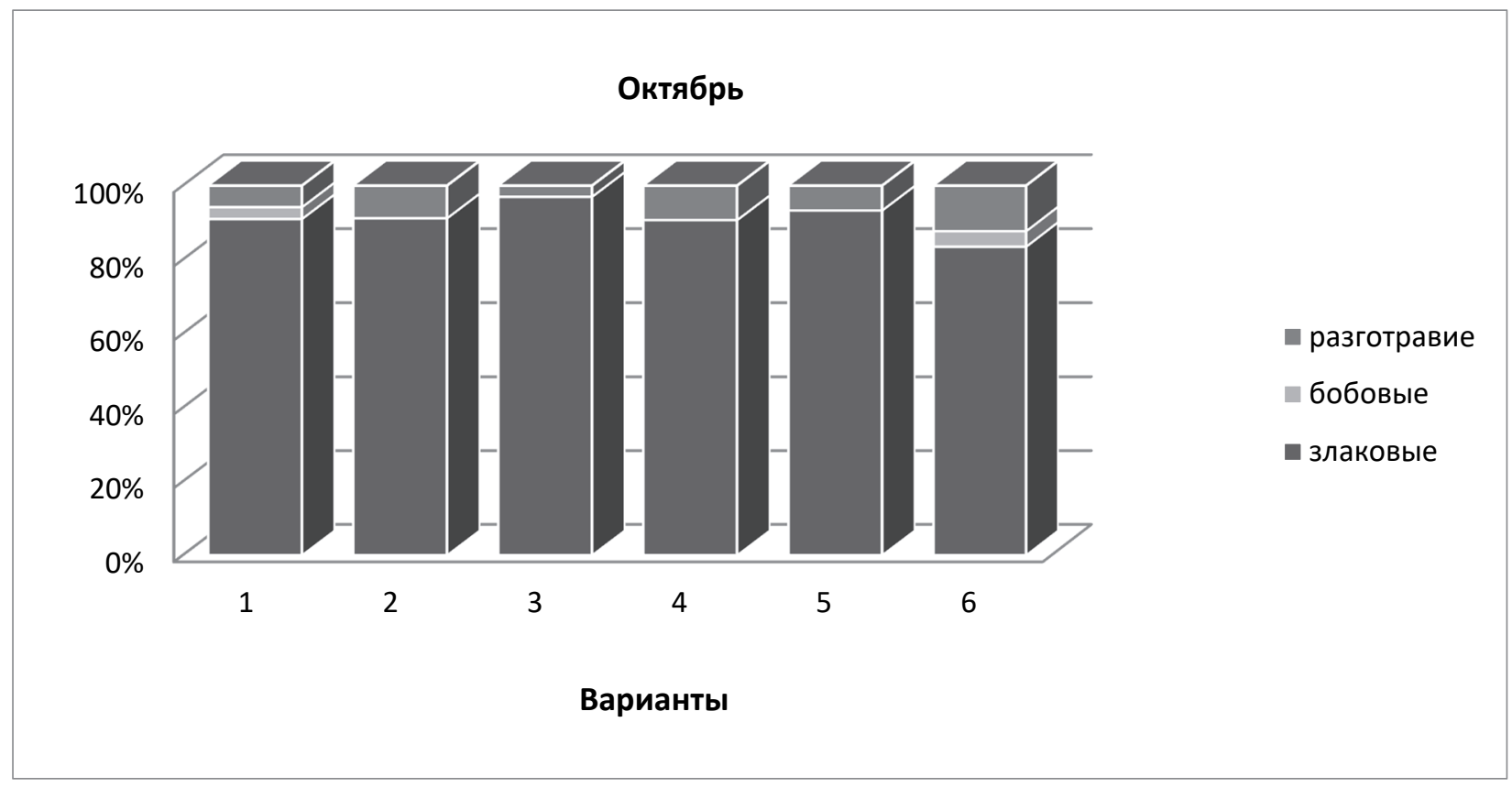

Рис. 2 Ботанический состав естественного травостоя в октябре месяце

Наблюдались следы Poa pratensis L., Alopecurus pratensis L., Festuca nigrescens L., Poa sylvicola L., Poa trivialis L. и другие. В отличие от злаковых, участие представителей бобовых Trifolium repens L., Torilis arvensis L., Trifolium arvense L. ограничено, как в весеннем, так в осеннем травостое. Это влияет на содержание белка и питательную ценность кормовой массы. На разнотравье наблюдается усиленное круглогодичное присутствие Rhinanthus. Наличие этого вида является показателем деградации естественного фитоценоза. Растительные сообщества изменяются под влиянием природных и экономических факторов. Изменения состава различных пастбищных угодий в Болгарии изучены и представлены в работах многих авторов $[5,18,19,20-23]$.

Климатическая характеристика района в период опыта. Значения температуры и осадков по результатам исследований в период пастбищного периода показаны на рисунке 3. 


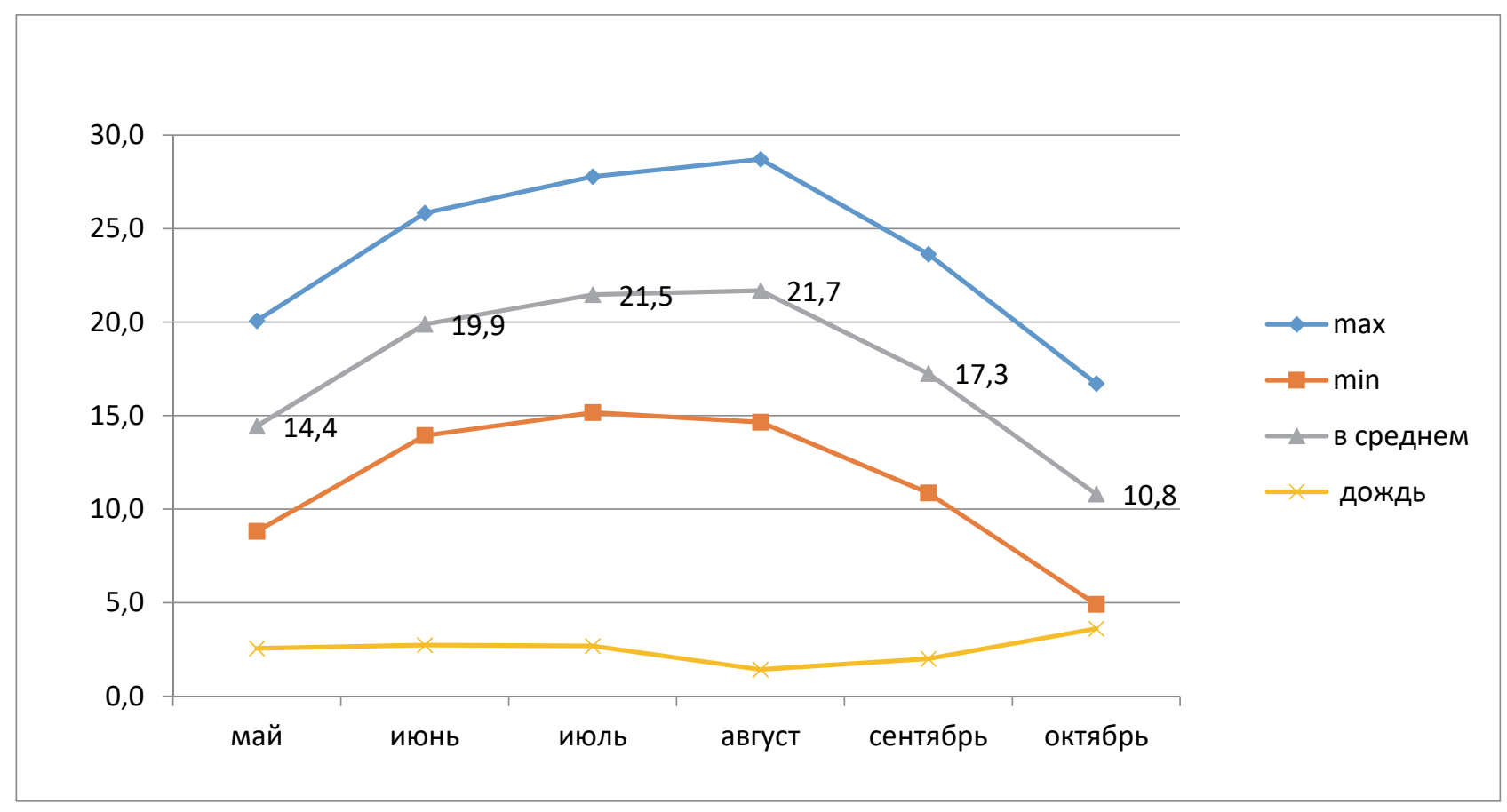

Рис. 3 Метеорологические условия в период исследования

Результаты показывают, что погодные условия влияют на состояние травы на пастбище. Дожди в мае, июне и июле составляют $2,7\left(\mathrm{Mм} / \mathrm{M}^{2}\right)$. Август - это месяц с самой низкой влажностью $\left(1,4 \mathrm{~mm} / \mathrm{m}^{2}\right)$. Самые высокие значения осадков регистрируются в октябре $-3,6\left(\mathrm{mм} / \mathrm{m}^{2}\right)$. Среднемесячная температура воздуха самая высокая в июле $\left(21,5^{\circ} \mathrm{C}\right)$ и августе $\left(21,7^{\circ} \mathrm{C}\right)$ и самая низкая в октябре $\left(10,8^{\circ} \mathrm{C}\right)$ с изменением от $4,9^{\circ} \mathrm{C}$ до $16,7^{\circ} \mathrm{C}$. В мае и июне измеренные средние температуры ниже, чем в июле и августе, в сочетании с более высоким количеством выпавших осадков. Сочетание температур и осадков в разные месяцы проводимых исследований определяют продуктивность пастбищ.

Выводы. У сформировавшегося в мае месяце травостоя высокое содержание сырой клетчатки, сырых жиров, минеральных веществ, кальция и фосфора, но более низкое содержание сырого белка $\left(102,35\right.$ г кг- $\left.{ }^{1}\right)$ и БЭВ $\left(325,23\right.$ г кг- $\left.{ }^{1}\right)$.

Более высокая урожайность зеленой и сухой массы в исследованиях в мае месяце (1780,00 кг/га зеленой и 684,23 кг/га сухой массы) является предпосылкой для удовлетворения потребностей животных достаточным количеством корма, содержащим необходимые питательные вещества.

Среднесуточный прирост телят в группе породы абердин-ангус несколько ниже в мае, июне и июле и колеблется от 0,487 кг до 0,597 кг. Дополнительный корм с кукурузной дертью позволил значительно его увеличить (1200 г-1680 г), увеличение наблюдалось в августе, сентябре и октябре.

Данные по ботаническому составу трав показывают, что в травостое в основном яровые и разнотравные виды трав, а процент бобовых культур слабо выражен.

\section{БИБЛИОГРАФИЯ}

1. The effect of high grass input feeding system compared to high concentrate input feeding system offered, to spring calving dairy cows in early lactation / E. Kennedy, M. O. Donovan, J. P. Murphy, F. P. O. Mara and C. Delahy // (Eds), XX International Grassland Condress:Offered papers, Wageningen Academic Publishers. - 2005. - P. 164-169.

2. Edwards, S. A. Intake of nutrients from pasture by pigs / S. A. Edwards // Proceeding of the Nutrition Society. - 2003. - Vol. 62 (2). - P. 257-265. 
3. Plant Production and nutritive quality of savannah-like grasslands in semi-arid zone of the province of Salamanca / L. Martin Polo, I. Garcia Belliolo and M. E. Sandches Rodriges // Spanish J. Agr., Res. - 2003. - Vol. 1 (4). - P. 41-49.

4. Тодорова, П. Състав, смилаемост и енергийна хранителност на зелена маса, сено и сенаж от естествен тревостой / П. Тодорова // J. Mountain Agr. On the Bolkans. - 2000. - Vol. 3 (2). P. 207-218.

5. Changes in the permanent grassland composition and feeding value during the growing season / P. Todorova // J-L. Durand, J-C. Emile, C. Huyghe and G. Lemaire / Eds / Multy-Function Grassland. Quality Forage. Animal Products and Landscapes Proc. $19^{\text {th }}$ General Meeting EGF, La Rochelle, France. - 2002. - P. 170-171.

6. Productivity and botanical composition of permanent grassland in the Central Balkan Moutains / P. Todorova // Proceeding of the $12^{\text {th }}$ Symposiym of the European Crassland Federation. - Pleven, Bulgaria 26-28 May 2003. - P. 64-66.

7. Дарджонов, Т. Повишаване на производството на говеждо месо / Т. Дарджонов. - София : Земиздат, 1987.

8. Тодоров, М. Съвременни системи за производство на говедовъдна продукция в планинските райони на България / М. Тодоров : дисертация / ИПЖЗ. - 2001. - Троян.

9. Али, Х. Анализ на производството на мляко и месо от говеда на пасищата в Средна Стара планина и насоки за подобряване / Х. Али : дисертация. - 2006.

10. Черекаев, А. В. Технология специализированного мясного скотоводства / А. В. Черекаев. - Москва : Колос, 1975. - 288 с.

11. Востриков, Н. И. Экономика и организация специализированного мясного скотоводства / Н. И. Востриков, Э. Доротюк. - Москва : Колос, 1982. - 205 с.

12. Отузбиров, Р. / Р. Отузбиров. : дисертация / Стара Загора. - 2001.

13. Кирилов, А. Ливадите и пасищата - важен фуражен ресурс за България и страните от ЕС / А. Кирилов, 3. Шиндарская, Е. Васильев. - Издателска къща при ЛТУ. - София. - 2013.

14. Effect of continuous grazing on forage quality, quantity and animal performance / V. Pavlu // Agriculture, Ecosystems and Environment. - 2006. - Vol. 113. - P. 349-355.

15. Baumont, R. Specific diversity in forages: its consequences on thefeeding value / R. Baumont, J. Aufrere, V. Niderkorn, D. Andueza, F. Surault, J. Peccatte, L. Delaby, P. Pelletier // Fourrages. 2008. - Vol. 194. - P. 189-206.

16. Kirilov, A. Development of forage areas and forage resources in Bulgaria during the period of transition / A. Kirilov, P. Todorova // Land use systems in grassland dominated regions, Grassland Science in Europe. - 2004. - Vol. 9. - P. 855-857.

17. http://www.mzh.government.bg

18. Найденова, Й. Спектроскопия в близката инфрачервена област (NIRS) за оценка хранителната стойност на фураж от ежова главица (Dactylis glomerata L.) през вегетацията и торене с азот и сяра / Й. Найденова, Д. Павлов // Постижения и перспективи на водния режим и минералното хранене на растенията в Бьлгария : II-ра Национална конференция : сб. / БАН, Институт по физиология на растенията, София. - 2001. - Т. 2. - Р. 60-63.

19. Найденова, Й. Калибрационни модели при отражателна спектроскопия в близката инфрачервена област (NIRS) за предвиждане хранителната стойност на фураж от житни и бобови треви / Й. Найденова, Д. Павлов // Животновъдни науки. - 2005. - Vol. 4. - P. 24-29.

20. Estimation of chemical composition and digestibility of perennial grasses by regression equations / Y. Naydenova, D. Pavlov, A. Katova, P. Day // Grassland Science in Europe. - Vol. 8, Optimal Forage Systems for Animal production and Environment, Eds. A. Kirilov, N. Todorov, I. Katerov, EGF - Int. Occ. Sym. Pleven, Bulgaria. - 2003. - P. 211-214.

21. Naydenova, Y. Plant cell walls fiber components analysis and digestibility of birdsfoot trefoil (Lotus corniculatus L.) in the vegetation / Y. Naydenova, A. Kyuchukova, D. Pavlov // Agricultural Science and Technology, International Journal Published by Faculty of Agriculture, Trakia University, Stara Zagora, Bulgaria. - 2013. - Vol. 5 (2). - P. 164-167. 
22. Naydenova, Y. Forage quality analysis and evaluation of perennial grasses in the vegetation. / Y. Naydenova // Field Crop Studies, Dobroudja Agricultural Institute, General Toshevo, Bulgaria 2012. - Vol. VIII (1). - P. 111-128.

23. Naydenova, Y. Forage quality analysis of perennial grass and legumes species in pure stands and mixtures / Y. Naydenova // Journal of Animal Science, Sofia. - 2014. - Vol. 18. (1-2). - P. 176183.

\section{REFERENCES}

1. Kennedy, E., M. O. Donovan, J. P. Murphy, F. P. O. Mara. and C. Delahy. 2005. The effect of high grass input feeding system compared to high concentrate input feeding system offered, to spring calving dairy cows in early lactation. XX International Grassland Condress:Offered papers, Wageningen Academic Publishers, 164-169 (in English).

2. Edwards, S. A. 2003. Intake of nutrients from pasture by pigs. Proceeding of the Nutrition Society, 62(2):257-265 (in English).

3. Martin Polo, L., I. Garcia Belliolo and M. E. Sandches Rodriges. 2003. Plant Production and nutritive quality of savannah-like grasslands in semi-arid zone of the province of Salamanca. Spanish J. Agr., Res. 1(4):41-49 (in English).

4. Todorova, P. 2000. Sъstav, smylaemost y enerhyina khranytelnost na zelena masa, seno y senazh ot estestven trevostoy - Ingredients, digestibility and energy nutrition of green mass, hay and natural grassland. J. Mountain Agr. On the Bolkans. 3(2):207-218 (in Bulgarian).

5. Todorova, P., and A. Kirilov. 2002. Changes in the permanent grassland composition and feeding value during the growing season. Multy-Function Grassland. Quality Forage. Animal Products and Landscapes. Proc. 19 th General Meeting EGF, La Rochelle, France, 170-171 (in English).

6. Todorova, P., D. Pavlov, and I. Petrova. 2003. Productivity and botanical composition of permanent grassland in the Central Balkan Moutains. Proceeding of the 12th Symposiym of the European Crassland Federation, Pleven, Bulgaria 26-28 May. 64-66 (in English).

7. Dardzhonov, T. 1987. Povishavane na proizvodstvoto na govezhdo meso - Increase of beef production. Sofija, Zemizdat (in Bulgarian).

8. Todorov, M. 2001. Sovremenni sistemi za proizvodstvo na govedovodna produkcija $v$ planinskite rajoni na Bulgarija - Modern systems for the production of cattle breeding in the mountain regions of Bulgaria. Disertacija, IPZhZ, Trojan (in Bulgarian).

9. Ali, H. 2006. Analiz na proizvodstvoto na mljako i meso ot goveda na pasishhata v Sredna Stara planina i nasoki za podobrjavane - Analysis of the production of milk and meat from cattle on the pastures in Central Stara Planina and guidelines for improvement. Disertacija (in Bulgarian).

10. Cherekaev, A. V. 1975. Tehnologija specializirovannogo Mjasnogo skotovodstva Technology of specialized beef cattle breeding. Moscow, Kolos (in Russian).

11. Vostrikov, N. I, and Je. Dorotjuk. 1982. Jekonomika i organizacija specializirovannogo mjasnogo skotovodstva - Economics and organization of specialized beef cattle breeding. Moscow, Kolos (in Russian).

12. Otuzbirov, R. 2001. Disertacija, Stara Zagora (in Bulgaria).

13. Kirilov, A., Z. Shindarska, and E. Vasilev. 2013. Livadite i pasishhata - vazhen furazhen resurs za Bulgarija i stranite ot ES - Meadows and pastures - an important feed for Bulgaria and EU countries. Izdatelska kъshha pri LTU-Sofija (in Bulgarian).

14. Pavlu, V., M. Hejcman, L. Pavlu, J. Gaisler, and P. Nežerková. 2006. Effect of continuous grazing on forage quality, quantity and animal performance. Agriculture, Ecosystems and Environment. 113:349-355 (in English).

15. Baumont, R., J. Aufrere, V. Niderkorn, D. Andueza, F. Surault, J. Peccatte, L. Delaby, and P. Pelletier. 2008. Specific diversity in forages: its consequences on thefeeding value. Fourrages. 194:189-206 (in English). 
16. Kirilov, A, and P. Todorova. 2004. Development of forage areas and forage resources in Bulgaria during the period of transition. Land use systems in grassland dominated regions, Grassland Science in Europe. 9:855-857 (in English).

17. http://www.mzh.government.bg (in Bulgarian).

18. Najdenova, J., and D. Pavlov. 2001. Spektroskopija v blizkata infrachervena oblast (NIRS) za ocenka hranitelnata stojnost na furazh ot ezhova glavica (Dactylis glomerata L.) prez vegetacijata i torene s azot i sjara. II-ra Nacionalna konferencija „Postizhenija i perspektivi na vodnija rezhim i mineralnoto hranene na rastenijata $v$ B'lgarija”, Sbornik, BAN, Institut po fiziologija na rastenijata, Sofija, 2:60-63 (in Bulgarian).

19. Najdenova, J., and D. Pavlov. 2005. Kalibracionni modeli pri otrazhatelna spektroskopija v blizkata infrachervena oblast (NIRS) za predvizhdane hranitelnata stojnost na furazh ot zhitni i bobovi trevi. Zhivotnovъdni nauki, 4:24-29 (in Bulgarian).

20. Naydenova, Y., D. Pavlov, A. Katova and P. Day. 2003. Estimation of chemical composition and digestibility of perennial grasses by regression equations. Grassland Science in Europe, Optimal Forage Systems for Animal production and Environment, EGF-Int. Occ. Sym. Pleven, Bulgaria, 8:211-214 (in English).

21. Naydenova, Y., A. Kyuchukova, D. Pavlov. 2013. Plant cell walls fiber components analysis and digestibility of birdsfoot trefoil (Lotus corniculatus L.) in the vegetation. Agricultural Science and Technology, International Journal Published by Faculty of Agriculture. Trakia University, Stara Zagora, Bulgaria, 5(2):164-167 (in English).

22. Naydenova, Y., 2012. Forage quality analysis and evaluation of perennial grasses in the vegetation. Field Crop Studies, Dobroudja Agricultural Institute. General Toshevo, Bulgaria, VIII(1):111-128 (in English).

23. Naydenova, Y. 2014. Forage quality analysis of perennial grass and legumes species in pure stands and mixtures. Journal of Animal Science. Sofia, 18(1-2):176-183 (in English).

УДК 636.2.034.061.082

\section{ЛІНІЙНА КЛАСИФІКАЦІЯ КОРІВ-ПЕРВІСТОК ЗА ЕКСТЕР'СРОМ ТА ЇЇ ЗВ'ЯЗОК З МОЛОЧНОЮ ПРОДУКТИВНІСТЮ}

\section{Г. Д. ІЛЯШЕНКО}

Кіровоградська державна сільськогосподарська дослідна станиія НААН (Созонівка, Украӥна) kirovogradgalina@ukr.net

Встановлено, щзо між рівнем надоїв за враховані першу і третю лактаиії та величиною показників оцінки будови тіла за 100-бальною системою існує достовірний додатній зв'язок. Збільшення оцінки за краший розвиток ознак, щчо характеризують будову тіла та якість вим'я, призводить до зростання надоїв корів як у першу, так $і$ в повновікову лактації. Результати градації підконтрольного поголів'я на класи згідно з міжнародною класифікаційною шкалою переконливо свідчать, щу рівень молочної продуктивності корів досліджуваних порід тотожний величині балів, отриманих за екстер'єрний тип.

Виявлений характер успадкування свідчть про можливість ведення селекиії в зазначеному напрямку і ефективного використання оцінених за потомством бугаӥв-поліпшувачів за ознаками екстер'єру.

Ключові слова: стадо, лінійна оцінка, будова тіла, молочна продуктивність, екстер'єрний тип, розвиток, сила впливу

Розведення і генетика тварин. 2018. Вип. 55 